\title{
0 debate teórico-metodológico na ciência política e 0 pensamento social e político brasileiro
}

\author{
The theoretical and methodological debate in political science and the \\ brazilian social and political thought
}

\author{
Marcelo Sevaybricker Moreira* \\ Doutorando em Ciência Política, Universidade Federal \\ de Minas Gerais - UFMG, Rua Juvenal dos Santos, 290, \\ 301/Luxemburgo, CEP 30380-530, \\ Belo Horizonte, MG, Brasil \\ e-mail:msevay@gmail.com \\ *autor correspondente
}

Recebido: 02/05/2012

Aceito: 10/06/2012
RESUMO O presente trabalho procura refletir criticamente sobre o lugar usual da teoria política e do pensamento social e político brasileiro no âmbito acadêmico e intelectual da moderna ciência política brasileira. Para isso, realizamos uma breve análise histórica da formação desse campo epistêmico nos Estados Unidos e no Brasil, destacando as semelhanças e diferenças desse processo nos dois países. Argumentamos contra uma visão naturalista e de inclinação positivista que contribui para que a reflexão teórica da política fique apartada da discussão mais empírica. Propomos, destarte, uma ciência política que seja capaz de incorporar a dimensão "subjetiva", a cultura política, como parte inerente à prática política do cotidiano, através do conceito de linguagens políticas. Essas linguagens, utilizadas pelos atores políticos, são inevitavelmente compostas de conceitos e valores, conferindo inteligibilidade à realidade política e conformando os interesses dos diversos grupos sociais em disputa.

PALAVRAS-ChaVe Ciência política; Teoria política; Pensamento brasileiro.

ABSTRACT The present work attempts to reflect critically on the usual place of political theory and brazilian social and political thought in the academic and intellectual of modern Brazilian political science. For this, we performed a brief historical analysis of formation of this field of epistemology and the United States and Brazil, highlighting the similarities and differences of this process in both countries. Argue against a naturalistic view and positivist inclination which contributes to the theoretical reflection of the political stand apart from the empirical discussion. We propose, thus, a political science that is able to incorporate the dimension "subjective," the political culture, as an inherent part of the political practice of everyday life, through the concept of political languages. These languages are used by political actors are inevitably composed of concepts and values, giving intelligibility to political reality and shaping the interests of various social groups in dispute.

KEYWORDS Political science; Political theory; Brazilian thought. 
A relação entre as ideias e as linguagens políticas, de um lado, e a própria realidade, de outro, está longe de ser de facilmente interpretada. A própria distinção terminológica falsifica essa relação, dando a impressão de que cada parte possa subsistir sem a outra, constituindo separadamente um "mundo cultural" ou "mental" e outro "material". Não é raro se defrontar com análises da política que a caracterizam como sendo moldada apenas pelo jogo de interesses individuais, como se a política pudesse existir na ausência de conceitos, valores e linguagens que a tornasse minimamente inteligível. Por outro lado, igualmente problemático, é supor (algo mais comum entre aqueles que se dedicam à teoria política) que as transformações da "cultura política" consistem num processo endógeno, "fora do mundo real". ${ }^{1}$

Começando pelo segundo equívoco, trata-se do que Raymundo Faoro chamou de "preconceito intelectualista". Concebe-se, no caso, a relação entre logos e práxis em três estágios: a primeira atividade é a do puro pensamento, quando o indivíduo tem em mente algo; haveria, destarte, "a proposição, enunciativa na sua consistência, premeditada, que levaria, por estímulo interno, à ação" (1994: 14). Em seguida, esse indivíduo escolhe os meios para a consecução do fim visado e, num último momento, teríamos a própria ação em sua concretude; em suma, "os eventos políticos seriam um reflexo da ideia" (Faoro, 1994: 14). Assim, a história da política poderia ser convertida na história das ideias, de modo que, ironiza o autor, o Contrato Social rousseauniano teria determinado a Revolução Francesa, assim como a Declaração de Independência, a Independência norte-americana.

A primeira perspectiva, por sua vez, sugere que a atuação dos atores políticos se orienta a partir de uma lógica pragmática e individualista, isto é, mediante a experiência e em função da maximização de suas necessidades e interesses, a despeito de quaisquer ideais ou quadro de valores; a práxis seria orientada apenas pela eficácia dos resultados, sem compromissos com ideias. No Brasil, análises desse tipo são encontradas nos meios de comunicação (na avaliação de jornalistas e declarações de políticos²), bem como na produção científica.

\footnotetext{
${ }^{1}$ Obviamente que o propósito aqui é acentuar as duas posições mais extremadas do debate, o que não inviabiliza analisar as posições intermediárias que se aproximam mais de uma ou de outra.

${ }^{2}$ Quando empossado como presidente do Partido dos Trabalhadores (PT), em 2010, o ex-senador José Eduardo Dutra afirmou o seguinte: "O PT tem tido uma evolução natural desde sua fundação. Quando foi fundado sofreu ataques, preconceitos da esquerda e da direita. Os partidos da esquerda tradicional, abrigados no PMDB, diziam que o PT dividiria a oposição. O PT tinha uma visão um pouco exclusivista. Por questão de sobrevivência, a gente não aceitava aliança. Em 2002,
}

Uma abordagem científica que expressa de modo exemplar essa última perspectiva é a de que a democracia pode funcionar bem independentemente da cultura, de modo que sua sobrevivência e sucesso dependeriam somente de alguns arranjos institucionais e da prosperidade de sua economia. Contrapondo-se aos diferentes matizes do culturalismo (do mais "fraco" ao mais "forte"), Adam Przeworski, José Cheibub e Fernando Limongi, por exemplo, defendem radicalmente que renda per capita, taxa de crescimento econômico e rotatividade de chefes de governo são os fatores determinantes para uma democracia sucumbir a uma ditadura e vice-versa. ${ }^{3}$

\begin{abstract}
Sustentamos que fatores econômicos e institucionais são suficientes para gerar uma explicação convincente da dinâmica das democracias sem que seja necessário recorrer à cultura. (Przeworski, Cheibub e Limongi, 2003: 10).
\end{abstract}

A concepção não-culturalista tem forte apoio empírico. Nessa visão a democracia sobrevive porque é mais vantajoso para as forças políticas relevantes, pautando suas ações por puro interesse próprio, obedecer ao veredicto das urnas do que fazer qualquer outra coisa. [...] Nesses termos, a democracia é um equilíbrio porque as forças políticas consideram que obedecer aos seus veredictos atende melhor aos seus interesses. (Przeworski, Cheibub e Limongi, 2003: 20-21, grifos nossos).

As culturas parecem ter pouco efeito sobre o estabelecimento da democracia, e nenhum sobre sua sobrevivência. (Przeworski, Cheibub e Limongi, 2003: 31).

\footnotetext{
chegamos à Presidência. Um partido que chega a administrar amplos espaços de poder tem que entender e se adaptar à realidade. Não pode perder seus princípios, mas também não pode ficar amarrado no principismo. Ou seja, o PT hoje é um partido pragmático" (Jornal $O$ Globo, 16/02/2010, grifos nossos). Mais recentemente, o jornal Valor Econômico noticiava a "Ascensão de um pragmático", a respeito de outro petista indicado para ser o relator da Lei Geral da Copa do Mundo de 2014, Vicente Cândido da Silva (Valor Econômico, 05/02/2011). O fato do PT ser caracterizado hoje como "pragmático", mais do que outros partidos, se deve, talvez, ao senso comum de que, antes de ganhar a presidência da República, o partido agisse mais em torno de ideais do que agora. Essa compreensão reforça o entendimento de que, quando se disputa efetivamente o poder, os ideais e valores não contam.

${ }^{3}$ Conclusões muito semelhantes são deduzidas em texto anterior, ainda que não em polêmica com o "culturalismo". "Se um país, um país qualquer selecionado aleatoriamente, deve ter um regime democrático no próximo ano, que condições deveriam estar presentes neste país e pelo mundo neste ano? A resposta é: democracia, riqueza, crescimento com inflação controlada, desigualdade decrescente, um clima internacional favorável e instituições parlamentaristas" (Przeworski et al, 1997: 113, ênfases dos autores).
} 
Seria interessante refletir como se pode conceber o ser humano, dotado de interesses, mas sem que esses interesses sejam afetados ou constituídos pelos seus valores, linguagens crenças, etc. Entretanto, cumpre destacar que a percepção de que os ideais políticos não afetam de modo significativo a realpolitik é também reforçada por diagnósticos do comportamento partidário, como os do brasilianista Scott Mainwaring. Em alguns de seus estudos (1998, 2005), este autor tem destacado que os cientistas sociais não deveriam supor que a competição entre partidos é sempre ideológica ou programática. No caso dos países que têm baixa institucionalização partidária, isto é, as democracias e semidemocracias menos desenvolvidas, como o Brasil, os partidos são fracos e indisciplinados, dando oportunidade ao voto de clientelista, ao populismo e aos políticos personalistas, de um modo geral. Nesse sentido, as próprias teorias espaciais do voto - dividindo-o em direita, centro e esquerda, por exemplo - são pouco úteis na compreensão do comportamento político dos eleitores e dos candidatos à eleição no Brasil, uma vez que a competição partidária aqui é difusa do ponto de vista ideológico. Uma consequência grave da fraca institucionalização do sistema partidário é que se torna difícil a accountability eleitoral, na medida em que os eleitores não conseguem identificar claramente os partidos e seus candidatos, vis-à-vis as suas promessas de campanhas e, por conseguinte, votar racionalmente em função dos interesses que perseguem. Concluindo, pragmatismo político seria o traço mais típico dos partidos no Brasil.

Em resumo, conforme essas concepções que minimizam o impacto dos ideais na dinâmica da política, o objetivo principal da Ciência Política consistiria, enfim, em identificar as variáveis ("não-culturais") que mais interferem no comportamento político dos indivíduos, quantificá-las, avaliar o seu impacto diferenciado, etc.

Isso significa também que, de acordo com essa visão frequente na ciência política, a teoria política (uma de suas subáreas), ao operar precipuamente com conceitos, valores, crenças e linguagens, funciona como um estoque de ferramentas necessárias e úteis ao cientista político em sua tarefa de categorizar, classificar, distinguir e identificar as instituições políticas, os atores da arena política, suas características, etc.; mas, ela é vista como algo que não "alcança" o senso comum e, por isso, diz respeito, em última instância, principalmente ao erudito. Se levarmos em conta a opinião de que a cultura tem pouco impacto sobre a política, então, torna-se mais fácil compreender porque a teoria política é vista como não-prioritária na ciência política mainstream, servindo apenas instrumentalmente ao balizamento do que realmente mais interessa: a análise empírica.

Terence Ball (2004) reconstrói o processo que ele denomina de "declínio da Teoria Política" no mundo acadêmico. Ele relata que, apesar de algumas reações contrárias, prevalecia, no século passado, um sentimento comum entre os especialistas de efetiva decadência dessa área, variando apenas da opinião daqueles que, como David Easton, decretavam entusiasticamente o fim dessa área de estudos (de modo análogo ao que se disse acerca do fim das ideologias, num mundo em que teria se difundido um consenso normativo nas democracias ocidentais), em prol de uma ciência política depurada de elementos históricos e normativos, aos que, como Sheldon Wolin, constatavam com pesar que esse campo estava realmente diminuído de importância.

Da metade dos anos de 1950 para o início dos 1970, mais ou menos, era de rigueur celebrar (se você fosse um "comportamentalista") ou lamentar (se você fosse um "teórico") o "declínio da Teoria Política". (Ball, 2004: 10).

A tendência de declínio da teoria política, por sua vez, pode ser interpretada como resultante do fato de que o modelo epistêmico dominante nessa área de conhecimento ser o norte-americano, como assevera Ball: "o isolamento da Teoria Política em relação à política sem dúvida teve bastante a ver com a dinâmica de profissionalização na academia norte-americana" (Ball, 2004: 17). É a ciência política estadunidense, com seu viés empiricista, que, em grande medida, estabelece um padrão de análise da política para o mundo com o qual não se conforma facilmente a teoria política:

A ciência política é uma invenção americana. Apesar de aparentemente exagerada, essa afirmação é em boa medida verdadeira. Claro que a ideia de um esforço sistemático de compreensão da política é coisa bem mais antiga. [...] Em suma, a invenção do estudo sistemático da política não pode ser atribuída aos americanos. O que estes fizeram, de fato, foi criar uma profissão acadêmica especializada no estudo da política e institucionalmente separada da História e da Filosofia. Mais tarde essa disciplina se diferenciaria também da Sociologia, da Psicologia e da Antropologia. (Feres Junior, 2000: 97, grifos nossos).

Em parte, por ter sido a vanguarda na criação da Ciência Política, a academia americana tornou-se modelo para os departamentos da Ciência Política em outros países e pólo 
exportador de tendências teóricas e temáticas. (Feres Junior, 2000: 98, grifos nossos).

[...] Todos sabemos da grande influência que, há décadas, as coisas da cultura americana exercem no Brasil. A necessidade de parecer americano são, para muitos, uma forma de escapar das frustrações de um Brasil que parece sempre ficar aquém das expectativas. [...] Essa é a condição do colonizado cultural. (Feres Junior., 2000: 107, grifos nossos).

De acordo com esse autor, o uso da expressão "ciência política" torna-se comum nos Estados Unidos a partir do debate entre federalistas e antifederalistas no século XVIII. Como disciplina acadêmica, porém, a ciência política neste país inicia-se em 1857, com a nomeação do primeiro catedrático nessa área; em 1880 é criado o primeiro departamento de ciência política e, em 1903, criada a APSA (Associação Americana de Ciência Política). ${ }^{4}$

Não é o caso aqui de rever em detalhes essa história, mas cumpre destacar que mais do que somente espaços acadêmicos distintos, como destaca João Feres Jr., são criadas nos Estados Unidos técnicas e práticas de pesquisa diversas das até então existentes e uma nova linguagem sobre a política. Trata-se de um movimento duplo: a afirmação de autonomia disciplinar aliada à criação de um novo discurso sobre a política; em suma, como diz Lessa, a constituição de uma "comunidade epistêmica", dotada de "identidade, recursos próprios, hábitos institucionais e linguagens próprias e compartilhadas e formas de expressão e presenças públicas" (2011: 29).

Discordamos parcialmente de Feres Jr. quando caracteriza a formação da ciência política brasileira e sua relação com os Estados Unidos como parte de um processo de colonização cultural. ${ }^{5}$ Há um claro exagero em afirmar que a ciência política no Brasil imite acriticamente a produção intelectual estadunidense (Moreira, 2008), pois mesmo que houvesse um empenho deliberado e comum por parte dos norte-americanos em alcançar isso (fato também objeto de controvérsia ${ }^{6}$ ), caberia ainda verificar como

\footnotetext{
${ }^{4}$ Visões menos críticas e igualmente informativas da história da ciência política norte-americana podem ser encontradas em Goodin e Klingemann (1998) e Almond (1998).

5 Sobre o processo de formação da ciência política no Brasil, sobretudo acerca de sua institucionalização, consultar: Lamounier (1980; 1982), Schwartzman (1991), Veiga (1992), Miceli (1993; 1995), Reis (1993) Oliveira (1995), Sorj (1995), Forjaz (1997), Vianna (1997), Almeida (2005) e Lessa (2010).

${ }^{6}$ Sem entrar demais nesse debate, cumpre mencionar apenas que mesmo o polêmico apoio de fundações estadunidenses (como a Fundação Ford) dado à ciência política brasileira na formação de professores, concessão de bolsas de pós-graduação para
}

nossos intelectuais reagiram a essa influência. Mais razoável nos parece a avaliação de Renato Lessa de que a "socialização de uma importante geração de cientistas sociais [...] nos temas e nos padrões disciplinares da Ciência Política norte-americana" é um fator absolutamente relevante na compreensão da formação da agenda de estudos da ciência política brasileira, apesar de isso não resultar forçosamente em mera

[...] clonagem do modelo original, ainda que uma cultura disciplinar fortemente afetada por uma inclinação positivista e por forte apego ao 'rigor metodológico' tenha permanecido como legado perene e constitutivo da nova identidade. (Lessa, 2010: 32).

É a ciência social norte-americana, empiricamente orientada, rompendo assim com a tradição ensaística e humanista das ciências sociais predominante na sociologia europeia e com uma ciência política marcada pela Filosofia do Direito. (Veiga, 1992: 65).

Como se vê, avaliação similar é atestada por Laura da Veiga acerca da "nova" ciência trazida para o país, para quem a complementação acadêmica de muitos brasileiros em cursos de pós-graduação, realizados em centros de excelência em ciência política nos Estados Unidos (sobretudo em doutorados), e mesmo a vinda de professores desses centros para a academia brasileira foi decisiva. Também segundo Elisa Reis (1993), tratava-se de consolidar um novo ethos de pesquisa, segundo o qual a pesquisa metódica e sistemática, de forte viés empiricista, tornava-se rotina para o cientista social brasileiro, rompendo, assim, com nossa tradição "ensaística". O mesmo afirma Sérgio Miceli, comentando o decisivo apoio dado à ciência política brasileira pela Fundação Ford, que visava:

[...] incentivar a construção institucional de programas de pós-graduação e de centros de pesquisa, dentro e fora das universidades; financiar o treinamento no exterior de cientistas competentes e futuras lideranças profissionais; subsidiar a introdução de disciplinas até então ausentes do mercado intelectual interno, mormente Economia, Demografia e Ciência Política;

\footnotetext{
intelectuais brasileiros, etc., se muitas vezes foi interpretado como evidência de nossa condição de "colonizado" (num contexto em que, hipoteticamente, era preciso combater com todas as armas o comunismo e aumentar a influência cultural estadunidense no mundo), é encarado por outros, como Sérgio Miceli, como um processo mais complexo em que inclusive se destaca a independência dessas fundações em relação às orientações políticas do governo norte-americano (Miceli, 1993).
} 
incentivar a adoção de uma nova divisão do trabalho científico com assimilação de novas técnicas como a do survey, com a formulação e execução de projetos de envergadura, com a incorporação de técnicas e métodos quantitativos; bancar o desenvolvimento de uma cultura acadêmica científica lastreada em padrões internacionais de desempenho e ancorada numa profissionalização das atividades e carreiras intelectuais; em suma, estimular a criação de uma verdadeira comunidade profissional fundada em padrões críticos e competitivos. (Miceli, 1993: 60, grifos nossos).

Parte desse legado estadunidense, como se disse, é precisamente o isolamento da teoria política em relação às demais subáreas da ciência política. Diversos trabalhos vinculam esse isolamento ao viés naturalista, positivista e anti-normativo que predominou na ciência política nos Estados Unidos e que teria surgido, ou se acentuado, a partir da chamada revolução behaviorista, nos anos de 1950, como diz Ball, anteriormente citado. Sobre isso, concordam Feres Jr. e Lessa:

[...] os cientistas políticos lançaram a behavioral revolution, um novo esforço de produção de uma Ciência Política objetiva aos moldes das Ciências Naturais. Um dos pontos programáticos da behavioral revolution era a separação da Ciência Política verdadeiramente científica da história do pensamento político e das teorias políticas normativas. Na prática, essa proposta levou à criação da teoria política como sub-área da Ciência Política, uma solução institucional que, segundo Gunnel, acabou causando o isolamento da teoria política das questões práticas mais candentes. [...] A análise da literatura de Ciência Política produzida atualmente nos EUA mostra que textos de teoria política, sejam eles clássicos ou modernos, são literalmente ignorados pela produção acadêmica das quatro sub-áreas mais "científicas" da Ciência Política: política americana, política comparada, relações internacionais e políticas públicas. (Feres Junior., 2000: 101, grifos nossos).

A virada [behaviorista] pretendia afirmar tal conhecimento como uma "ciência", com protocolos distintos daqueles utilizados pela Filosofia Política, percebida como contaminada por fortes componentes historicistas e normativos. [...] Os adeptos da revolução dirigiram pesadas críticas à tradição da Filosofia Política - ou da Teoria Política. (Lessa, 2010: 36, grifos nossos).
Lessa avalia esse processo como parte resultante de um projeto educacional mais amplo. De acordo com ele, por volta dos anos 1940 e 1950 ocorreu nos Estados Unidos um processo de uma "virtual refundação" de boa parte do ensino superior, incluindo a economia, a filosofia e a ciência política, a fim de superar um suposto "legado ideológico da década de 1930" (Lessa, 2010: 34). Essa "refundação" consistiu na afirmação de quatro princípios básicos: 1) devoção às ciências duras; 2) busca pela objetividade do conhecimento; 3) confiança na análise formal; 4) aversão às ideologias e anseio de "pureza disciplinar" (Lessa, 2010: 35). A "refundação" fez com que essas áreas perdessem uma disposição de função pública e de maior interlocução com a sociedade, caracterizando-se, doravante, por valorizar mais os marcadores internos de "qualidade" da ciência, como expressos pelo crescente profissionalismo na área (via o treinamento sistemático dos estudantes nas disciplinas específicas) e pela autonomia acadêmica (e não segundo os parâmetros de uma cultura humanista e transdisciplinar como ocorria mais anteriormente). Assim como a economia afastava-se da tradição da economia política, em especial das proposições keynesianas, aproximando-se, por sua vez, da econometria e incorporando uma linguagem mais formal, a filosofia convertia-se à virada linguística, distanciando-se da tradição mais clássica de discussão ética e normativa, e a ciência política inaugurava uma nova linguagem para tratar a política, a partir de modelos formais com forte destaque à estatística e à pesquisa empírica.

Mas, adverte o autor, o behaviorismo "não reinou de forma exclusiva e absoluta" nos Estados Unidos (Lessa, 2011: 42). Já em meados de 1960, David Easton, um daqueles que celebrara a "revolução", identificava uma virada pós-behaviorista, constituída principalmente a partir das críticas à alegada neutralidade dos cientistas políticos numa América crescentemente politizada. Gabriel Almond também discute os desdobramentos do pós-behaviorismo, pós-cientificismo e das perspectivas desconstrutivas de uma visão neutra da ciência política e de seu viés empiricista. Contestando àqueles que asseveram que não há mais uma identidade desse campo, tendo em vista seu crescente pluralismo, Almond procura reafirmar essa identidade, numa perspectiva que une o trabalho dos filósofos antigos aos dos cientistas políticos contemporâneos:

Nosso tratamento neste capítulo avança e demonstra numa perspectiva histórica que há uma versão privilegiada de nossa história disciplinar e que é progressiva, medida pelo aumento de conhecimento e baseada na evidência 
e na inferência. Isso incluiria o trabalho de escolas opostas, na medida em que satisfazem essas regras. Excluiria as reivindicações e proposições não fundadas nas evidências, ou não-falsificáveis pelas análises lógica e de provas. Objetiva, rigorosa, acadêmica é de fato o perfil privilegiado em nossa história disciplinar. (Almond, 1998: 83, tradução e grifos nossos). ${ }^{7}$

Mesmo admitindo que esse campo de conhecimento também conheceu suas fraturas e tensões internas com o próprio padrão positivista a que se fez referência, permaneceu influente o axioma behaviorista (como se vê pela própria reafirmação dele por Almond ao dar prioridade ao rigor e à objetividade científica), de que as ciências naturais são um modelo epistêmico a ser emulado pelos cientistas políticos. Nesse caso, caberia a eles encontrar leis ou padrões, bem como formular modelos dedutivos que pudessem, rigorosamente, explicar os fenômenos políticos. Como a démarche da teoria política parece ser mais interpretativa do que explicativa, além de eminentemente normativa e histórica, essa subárea acaba tornando-se periférica, tendo, conseguintemente, de ser utilizada topicamente, ou pensada como um campo autônomo que, por seu turno, pouco tem a dizer às outras subáreas da ciência política.

\section{O positivismo filosófico teve, por assim dizer, uma função normativa ou reguladora do comportamentalismo, em que o positivismo definiu para os comportamentalistas o que é a "ciência" - e o que a Ciência Política deveria ser, se fosse para ser uma ciência. Primeiramente, a Ciência Política deveria distinguir entre "fatos" e "valores". Em segundo lugar, ela deveria ser "empírica" ao invés de "normativa". E, por fim, ela deveria ser explicativa no sentido acima indicado. Toda explicação genuinamente científica, de acordo com os critérios positivistas de suficiência explicativa, depende da descoberta e do desenvolvimento de "leis" universais e eternas. \\ Boa parte da Teoria Política "tradicional" não se conformava aos critérios positivistas de significância cognitiva e suficiência explicativa. Por esses motivos, ela foi rejeitada como não-científica e, portanto, destinada a ser}

\footnotetext{
Our treatment in this chapter advances and demonstrates in its historical account that there is indeed "privileged" version of our disciplinary history and that is a progressive one, measure by the increase of knowledge based on evidence and inference. It would include the work of opposing schools, insofar as it meets these standards. It would exclude those claims and propositions not founded on evidence, or not falsifiable through evidence and logical analysis. Objective, rigorous, scholarship is indeed the privileged thread in our disciplinary history.
}

superada no devido tempo. (Ball, 2004: 13, grifos nossos).

Como se sabe, a Teoria Política é tida como a subárea que tipicamente se constitui não apenas de um repertório crítico sobre a política tal como praticada, como também de um conjunto de prescrições normativas de como a política deve ser. Ora, se a ciência política assumia a separação positivista entre fatos e valores, voltando-se supostamente apenas para os primeiros, estava claro porque a dimensão teórica não poderia mais compor o núcleo principal dessa ciência.

Cícero Araújo e Bruno Reis diferenciam alguns dos principais momentos desse processo de formação e consolidação da ciência política nos Estados Unidos, sofisticando o diagnóstico acima descrito. Segundo eles, numa primeira fase, desponta o esforço inicial de "delimitação concreta dos objetos de estudo e no aperfeiçoamento da pesquisa empírica e dos métodos e técnicas para esse propósito" (Araújo e Reis, 2005: 57), como tipificam os estudos de comportamento eleitoral. Como os autores reconhecem, havia inequivocamente um "certo frissom de superação da Filosofia" (Araújo e Reis, 2005: 58). Numa etapa posterior, já se verificava um aumento relativo no interesse pela teoria política quando se expande a chamada rational choice, a teoria da escolha racional ou pública, isto é, os estudos que, baseados em modelos econômicos (particularmente da microeconomia) tentam explicar o comportamento dos atores políticos, sobretudo em uma democracia. Entretanto, como eles reconhecem, boa parte dos cientistas políticos se contentavam em elaborar modelos abstratos para avaliar os dados empíricos, fazendo, desta feita, um uso limitado da teoria; ademais, deve-se acrescentar que o uso da teoria nessa escola tende a recorrer, quase exclusivamente, às tradições que operam com o conceito de racionalidade instrumental. A mobilização pontual da teoria política pode ser encontrada também num terceiro desdobramento, constituído pelas correntes que acentuaram a importância das instituições na explicação da política, o chamado neo-institucionalismo. Se antes, na rational choice, o diálogo interdisciplinar se dava mais com a economia, agora ele ocorre em especial com a área do direito, e não com a teoria política, embora houvesse inúmeros elementos nessa área, desde pelo menos a filosofia de Aristóteles, com a reflexão acerca do papel das instituições na dinâmica política. Poderíamos destacar um quarto desdobramento igualmente importante nos primeiros momentos da ciência política estadunidense (embora seja menos uma corrente de pensamento, como as demais, e mais uma área temática), que recebeu forte influência da rational choice e com 
reflexos na produção científica internacional, as chamadas policy sciences, ou políticas públicas. Subárea da ciência política surgida nos princípios da década de 1950, incorpora boa parte dos pressupostos behavioristas antes elencados: neutralidade de valores, cientificidade, quantificação como característica elementar do método de pesquisa e preponderância dos estudos empíricos, em detrimento de uma perspectiva mais teórica.

Sintetizando a discussão desenvolvida até aqui, podemos dizer que as policy sciences nasceram sob forte influência do pensamento acadêmico que dominava as Ciências Sociais até a década de 1950, caracterizada pela ênfase no "rigor científico". Nas policy sciences, essa atitude cientificista levou ao enaltecimento dos métodos quantitativos e ao foco privilegiado nos modelos econômicos. Com isso, muitas vezes, o método subordinou a própria teoria. (Andrews, 2005: 31, grifos nossos).

Andrews procura destacar como a subordinação da teoria ao método, nas políticas públicas, produziu uma hipostasia ou reificação da realidade social, na medida em que os cientistas políticos consideravam os dados coletados como fatos independentes da própria pesquisa. A busca pelo rigor metodológico tendia, assim, a substituir uma discussão teórica, que, se feita de modo mais apropriado, levaria em consideração o processo de criação das categorias analíticas pelo pesquisador, tidos então como "fatos puros". Vê-se novamente que a preocupação quanto à objetividade do conhecimento levava a um tratamento secundário e, por isso, mais precário da discussão teórica. Elemento adicional e politicamente relevante é a declarada intenção de que os trabalhos científicos de políticas públicas servissem aos governantes como instrumento de aperfeiçoamento de suas decisões, tornando-as mais "racionais", constituindo esse saber numa forma de "engenharia social" (Andrews, 2005: 18).

Embora assumissem uma postura de imparcialidade, como boa parte dos cientistas políticos norteamericanos da época, vê-se que, paradoxalmente, defendiam abertamente a superioridade do regime democrático, em especial tal como vivenciado nos Estados Unidos. A mesma incoerência é notada por Lessa, para quem era frequente a combinação de um discurso de neutralidade quanto a valores e, ao mesmo tempo, de compromisso com os ideais liberaldemocráticos. Lessa e Andrews concordam também que esses valores incorporados pelos cientistas políticos estadunidenses devem ser compreendidos à luz do contexto político internacional da década de 1950, isto é, de intensa disputa ideológica entre capitalismo (à la Estados Unidos) e socialismo (como na União Soviética); isso não significa que eles tenham aderido invariável e totalmente aos valores do anticomunismo, mas de algum modo respondiam ao debate típico da Guerra Fria.

Em suma, a história da ciência política estadunidense é mais complexa do que a "caricatura" que retrata todo esse campo de estudos submetido uniforme e permanentemente aos pressupostos da revolução behaviorista (Lessa, 2010: 38), mas não deixa, todavia, de evidenciar uma forte tendência behaviorista, de afirmação de um tipo de ciência que se quer empírica, objetiva, mormente neutra e que, por tudo isso, se afasta da reflexão "puramente teórica". Ao afastar-se da teoria ou ao utilizar-se limitada e instrumentalmente dela, a ciência política norte-americana acabava por reificar a realidade política vigente (tratando marginalmente todas outras realidades políticas normativamente vislumbradas como excessivamente utópicas e impossíveis) e, de modo incongruente com os princípios de uma ciência axiologicamente neutra, endossando-a, com um suposto status científico de racionalmente superior, sob o modelo da democracia liberal e eleitoral estadunidense.

Cumpre salientar um segundo aspecto desse processo intelectual. Além das aparentes incompatibilidades entre as abordagens "empírica" e "teórica" da política, mencionadas acima, uma das razões aludidas no mainstream da ciência política norte-americana para justificar o seu afastamento da teoria política, era de que os estudos nessa área haviam se voltado sobre si mesmos, gerando um "culto ao antiquarismo" (Feres Junior, 2000: 101) e redundando em um conhecimento inócuo ou em pura "história das ideias" (Lessa, 2010: 36).

Segundo eles [os adeptos à revolução behaviorista], esse campo teria esgotado sua capacidade de inovação intelectual e, dessa forma, refluído para um mero esforço historiográfico a respeito dele próprio. (Lessa, 2010: 36, grifos nossos).

Obviamente que essa avaliação torna-se razoável quando se tem como padrão as ciências naturais. Não faz, de fato, sentido esperar que o campo teórico produza um conhecimento de tipo idêntico ou semelhante ao das ciências da natureza - ou ao que se idealiza normalmente a respeito do conhecimento que essas últimas produzem. Num cenário de forte conotação positivista ou neopositivista, restava à teoria política, portanto, contentar-se com seu espaço marginal dentro da ciência política.

Terence Ball estabelece uma distinção sobre o trabalho teórico que (apesar dele próprio dela mais tarde abdicar, dada a sua simplificação) nos é útil para 
pensar esse problema. Conforme sua interpretação há uma teorização de primeira ordem e outra de segunda ordem. A de primeira ordem é suscitada por questões candentes da sociedade, tais como justiça, equidade, obediência à autoridade civil, etc.; tratam-se dos estudos mais normativos de teoria política, como tipifica o clássico texto de John Rawls, A theory of justice. A teorização de segunda ordem consiste, por sua vez, em "estudar, ensinar e comentar os 'clássicos' do pensamento político" (Ball, 2004: 12). Para ele, foi o segundo tipo de pesquisa que, infelizmente, acabou prevalecendo no universo acadêmico anglo-saxão até os anos 1970, quando, então, se tem um reavivamento da teoria política.

\section{Em contraste, muito do que se passa por Teoria Política na academia deveria, de maneira geral, ser denominado de teorização de segunda ordem. [...] A Teoria Política, tal como praticada nos departamentos de Ciência Política, foi relegada a uma espécie de limbo ou morte viva: o pior tipo. Muitos do que praticaram a teorização de segunda ordem não se sentiam bem-vindos e alguns foram mesmo encorajados a negociar suas transferências para os mais congeniais departamentos de Filosofia ou História (Ball, 2004: 12, grifos nossos).}

Vê-se que, mesmo entre os "entusiastas" do retorno da teoria política, como Ball, entende-se que as teorizações de segunda ordem são de menor importância do que as de primeira. Ou como ele diz adiante: mais importante do que aprender sobre (Platão, Aristóteles, Hobbes, etc.) é aprender com. Todavia, ao contrário do que supõe o autor, os estudos históricos não precisam necessariamente se limitar à exegese dos "clássicos", assim como as "teorizações de primeira ordem" nem sempre se ocupam dos temas mais relevantes para a sociedade.

Em instigante artigo, Donald Kelley discorre sobre as heranças e perspectivas no mundo acadêmico da história das ideias; cumpre destacar algumas de suas reflexões para o presente debate. Em primeiro lugar, o autor assevera que essa área de conhecimentos é muito mais do que a história da filosofia, como dá a entender Ball; muito mais eclética do que a segunda, ela não se resume à análise dos textos canônicos da filosofia (embora essa seja uma forte tendência a esse campo), reunindo ao mesmo tempo estudos sobre literatura, ciência, economia, folclore, arte, política, religião, etc. Ao contrário da outra, a história das ideias não se limita à análise das "ideias puras", mas também ao seu uso ideológico e social. O campo da história das ideias políticas, portanto, no qual se insere também esta pesquisa, é tão somente um dos assuntos sobre os quais têm se ocupado os historiadores das ideias, mas se diferencia da história da filosofia por dedicar especial atenção ao significado político das ideias.

\begin{abstract}
Numa visão mais ampla, então, a história intelectual não precisa (ou não precisa mais) ser identificada com o cânone da filosofia, com o tema da alta cultura, com constrições sociais e elitistas, com as teorias intelectualistas da causalidade na história. Ao contrário, deve ser vista como uma abordagem ou com uma gama de abordagens, com a investigação histórica e de interpretação em geral - abordagens que começam com formas culturais e linguísticas, mas que não necessariamente presumem as convenções formais e lógicas do discurso acadêmico. O assunto dos historiadores intelectuais são textos, ou seus análogos culturais; o campo inteligível de estudos" mais geral é a linguagem, ou linguagens, e a história da filosofia não é o modelo, mas sim uma província nesta arena maior de interpretação. (Kelley, 1990: 19, trad. e grifos nossos). ${ }^{8}$
\end{abstract}

Deixando por ora essa digressão de lado, cumpre esclarecer que no Brasil a revolução behaviorista não se deu do mesmo modo e com a mesma intensidade, indicando, como já afirmamos acima, que não se trata de relações intelectuais meramente reflexas. Lessa observa que isso talvez tenha ocorrido pelo fato de que o contato de nossos intelectuais com essa cultura tenha se dado num momento de crise da abordagem comportamentalista, e em que já despontavam visões críticas e alternativas a ela. Entendemos que a ideia de um "simples contágio", como demonstra Faoro (a respeito da formação do liberalismo brasileiro em relação à tradição do liberalismo europeu e norte-americano [1994: 63]), dificilmente esgota as complexas relações entre intelectuais de diferentes países, como é também o caso dos cientistas políticos brasileiros em relação a essa cultura acadêmica estadunidense. Mesmo o fato, realçado por Lessa, de termos sido "expostos" a um behaviorismo enfraquecido deve apenas compor o quadro mais geral de interpretação desse processo, a ser constituído também por certos elementos próprios à cultura brasileira, como a forte tradição de

\footnotetext{
In the broadest view, then, intellectual history need not (or need no longer) be identified with the canon of philosophy, with the subject of high culture, with elitist social constrictions, or with intellectualist theories of causation in history. Rather it should be seen as an approach, or range of approaches, to historical investigation and interpretation in general - approaches which begin with cultural and linguistic forms but which do not necessarily presume the conventions of academic or even formally logical discourse. The subject of intellectual historians are texts, or their cultural analogues; "the intelligible field of study" more generally is language, or languages; and the history of philosophy is not the model of but rather a province in this larger arena of interpretation.
} 
pensamento político já existente no país, e o elemento mais geral de recriação crítica das categorias analíticas por nossos pensadores a fim de se compreender o país e suas idiossincrasias (Moreira, 2008).

Mesmo estando sob a influência dessa cultura e incorporando várias de suas características - "[...] a forte preocupação metodológica, com ênfase quantitativa, e um claro movimento de [...] autonomização da política, com relação a outros domínios cognitivos." (Lessa, 2010: 39) - os cientistas políticos brasileiros se mostraram críticos a alguns aspectos dessa "virada". Um deles é a alegada abordagem neutra da política. Aqui "incorporava-se certo ethos cientificista, mas ao mesmo tempo praticava-se a crítica de uma política apolítica" (Lessa, 2011: 46). Não se replicou no país o discurso de separação entre o cientista e o militante: boa parte de nossos politólogos participaram ativamente dos debates e movimentos públicos, dando continuidade, em alguma medida, à tradição prévia de pensamento político que, não obstante, alguns deles renegavam. Por fim, é possível constatar ainda que não ocorreu uma marginalização tão intensa da teoria política. Sobre isso, Lessa salienta a postura de dois expoentes da ciência política acadêmica no Brasil, Fábio Wanderley Reis e Wanderley Guilherme dos Santos, que concederam significativa atenção aos temas da filosofia contemporânea. Em função dessas diferenças, considera-se que a ciência política brasileira acabou se tornando muito mais plural do que a "matriz" estadunidense.

Mas, mesmo que em menor grau, se a teoria política não se isolou completamente da ciência política mainstream no Brasil, também não conseguiu se estabelecer de modo significativo dentro dela. Também aqui os estudos teóricos são, mormente, compreendidos ou como instrumento da análise empírica, o fim último da atividade do cientista político, ou como trabalhos auto-referidos de construção de modelos ideais da política ("teorização de primeira ordem"). ${ }^{9}$ São escassos os estudos de teoria política que procuram esclarecer a relação identificada no início desta seção, a saber, entre ideias, crenças e linguagens políticas e a prática política cotidiana no país, como se as primeiras tivessem pouca influência sobre a segunda.

Na discussão sobre metodologia que acompanha a ciência política brasileira hoje se constata, de fato, o desprestígio da teoria. Renato Lessa observa

\footnotetext{
Em pesquisa sobre a pós-graduação em ciência política no Brasil, Maria Hermínia Tavares de Almeida constata que quase a totalidade dos artigos publicados em periódicos nacionais de ciência política e que tratam de teoria política se dedica à teoria contemporânea, com forte atenção normativa (2005: 117).
}

que a reivindicação de maior atenção ao método, muito comum no meio, não é acompanhada de uma discussão de filosofia da ciência e de teoria do conhecimento, o que explica, em grande medida, o viés do treinamento metodológico ao qual são expostos os estudantes de ciência política no Brasil, numa perspectiva claramente "afilosófica" (2011: 44).

Fábio Wanderley Reis, por exemplo, identifica uma involução no ensino e utilização de metodologia nessa área no Brasil, do fim dos anos 1970 ao final da década de 1990 , o que, para ele, faz com que os trabalhos assumam um perfil predominantemente descritivo, "de cunho jornalístico, historiográfico, etnográfico" (Reis, Reis e Velho, 1997: 8). Contra um contorno mais "humanista" e "idiográfico" de ciência - como seria próprio à História e à Antropologia - Reis argumenta que "a Sociologia e a Ciência Política encontram-se claramente mais próximas do padrão 'científico', caracterizado pelo apego ao rigor, à sistematicidade, à generalização e à busca de cumulatividade" (Reis, Reis e Velho, 1997: 9); seriam, portanto, ciências nomotéticas. Note-se, por conseguinte, que embora esse autor reivindique maior espaço à teoria política no âmbito da ciência política, ele concebe a primeira dentro dos marcos da behavioral revolution, como se evidencia, em extensa mas representativa passagem, pela sua visão do que é produzido em ciência política:

Se me pedem uma comparação geral do avanço e qualidade da ciência social feita no Brasil com a de outros países, creio que dá pra dizer algo a respeito da Ciência Política. [...] Acho possível dizer que a França praticamente não tem Ciência Política de maior interesse. Na Inglaterra há a tradição erudita e ritualista de political theory, que produz com abundância trabalhos agradáveis de se ler mas que me parece uma tradição predominantemente estéril. Os eternos comentários sobre os clássicos, o eterno voltar a Hobbes, Locke... [...] Mas os Estados Unidos são claramente o país onde de fato as coisas acontecem, e não há como deixar de destacar o seu papel, que tende a criar um forte efeito de gravitação e a incorporar de um jeito ou de outro o que a aparece de melhor na Europa [....]. E a importância dos Estados Unidos se dá não só no que se refere à produção da disciplina vista de maneira mais convencional, mas também no plano das relações com outras disciplinas, que têm tido consequências extremamente dinâmicas e positivas, como é o caso, em particular, das relações com a Economia, com o forte impacto do estabelecimento e difusão da abordagem da escolha racional. A força desse impacto se mostra mesmo, aliás, de maneira meio surpreendente, na revivescência da própria 
filosofia política, claramente influenciada pelo impacto da perspectiva analítica básica que levou ao florescimento da escolha racional (a welfare economics etc.), como no caso da obra de John Rawls, por exemplo. (Reis, Reis e Velho, 1997: 15-16, grifos nossos).

Vários pontos antes discutidos emergem novamente a partir dessa ilustrativa citação: a centralidade da ciência política estadunidense, a irrelevância de outras tradições mais próximas à história e à filosofia (França e Inglaterra) e a preeminência das teorias que operam centralmente com a noção de interesses e de racionalidade instrumental, como a rational choice. Avaliação muito semelhante reaparece em dois outros trabalhos importantes de balanço da ciência política brasileira, o de Olavo Brasil de Lima Jr. e o de Gláucio Soares.

Segundo o primeiro, a produção em ciência política por aqui fica marcada por "trabalhos eminentemente ensaísticos e jornalísticos" e por um certo "[...] ensaísmo de cunho semifilosófico ou de história das ideias, baseado em fontes secundárias." (Lima Junior, 1999: 18). O autor considera que contra essa tendência, deve-se tomar como "[...] requisito essencial para o treinamento do cientista político [...] cursar disciplinas de alto nível de formação quantitativa." (Lima Junior, 1999: 49, grifos nossos).

Gláucio Soares, como os demais, se ressente da formação acadêmica dos cientistas políticos brasileiros, constituindo o que ele chama de "calcanhar metodológico". O autor entende que o país "anda na contramão da história” (2005: 73), pois enquanto a ciência política internacional se dedica sistematicamente à utilização de métodos quantitativos e qualitativos de pesquisa, ao treinamento dos estudantes em técnicas de pesquisa e estatística, aqui se criou uma aversão à utilização dos primeiros e uma discussão muito mais "epistemológica" do que "metodológica" (Soares, 2005: 77), redundando em simples "ensaios" sobre política (Soares, 2005: 85). Diversas passagens do texto de Soares expressam claramente a permanência e força do ethos behaviorista, contra, portanto, a um perfil mais plural da ciência política brasileira. Além disso, o autor afirma que a utilização de teoria no Brasil é distinta do modo usual de se proceder nas universidades anglo-saxãs e escandinavas. Aqui "[...] as teorias se limitam a um cansativo cardápio requentado de 'grandes clássicos'." (Soares, 2005: 90), repetindo aqui o topos argumentativo presente nos outros dois autores citados, ao passo que no estrangeiro, a teoria é criada para solucionar problemas práticos da sociedade. Nesse sentido, o autor critica seus pares de serem "colonizados" teoricamente, recorrendo aos autores tradicionais do Primeiro Mundo, Habermas, Bourdieu, Marx, Weber, etc., oriundos dos países centrais, e ignorando a produção nacional e do Terceiro Mundo. Ironicamente, pode-se dizer que a mesma imputação de "alienação" atribuída por Soares aos cientistas políticos brasileiros, poderia ser feita a ele próprio, na medida em que critica a ciência política nacional por não atender aos parâmetros dominantes dessa ciência no mundo, particularmente como é praticada nos Estados Unidos.

Percebe-se, portanto, que para a maioria dos cientistas políticos, como revelam os textos de Reis, Lima Jr. e Soares, nossa formação acadêmica é deficiente no tocante à metodologia por não enfatizar ainda mais o treinamento dos estudantes em técnicas de pesquisa quantitativas e qualitativas, como ocorre nos países centrais. Por outro lado, é exatamente contra essa defesa que argumenta Lessa - representando uma posição claramente minoritária na ciência política nacional e com o qual concordamos - na medida em que essa formação ou que a sua modificação nos parâmetros defendidos pelos autores supracitados acentua a distância entre "teoria" e "empiria", além de subordinar a primeira à segunda. Mesmo no Brasil onde a "teoria" encontrou mais espaço na ciência política do que nos Estados Unidos, enraíza-se, conseguintemente, a diferenciação entre os "estudiosos de teoria" e os "estudiosos da empiria", replicando, nesse caso, a mesma distinção típica do mundo acadêmico norte-americano. A respeito desse tema, avaliam criticamente Araújo e Reis, sobre a situação brasileira, bem como Ball sobre a situação nos Estados Unidos:

O principal problema resultante é que essa situação tende a gerar, em vez de uma simples divisão do trabalho que viesse a bem da produtividade global da área, dois tipos de profissionais que frequentemente comunicam-se de modo precário. (Araújo e Reis, 2005: 64, grifos nossos).

A divisão do trabalho curricular convencional designa aos teóricos a tarefa de traçar e avaliar ideias, ideais e crenças, deixando para os investigadores empíricos a tarefa de descrever e explicar o efetivo comportamento dos agentes políticos. Essa divisão do trabalho sugere que há dois domínios bem separados, um do pensamento ou de "teoria" e o outro da ação ou do "comportamento", cada qual podendo ser bem caracterizado sem referência ao outro. Mas essa divisão é notadamente falsa. O agente que tem certas crenças não é separável do agente que atua. De fato, suas ações não são nem mesmo descritíveis sem referência às suas crenças - e vice-versa. Assim, a esperança de 
criar uma ciência do "comportamento" político era em tudo tão equivocada quanto uma "história do pensamento político" isolada. (Ball, 2004: 19, grifos nossos).

No caso brasileiro, acrescenta-se outro fenômeno digno de nota: a teoria política (como subárea da ciência política) se distancia da filosofia política e das humanidades em geral (repetindo, ainda que com menor intensidade, a tendência norte-americana), enquanto a primeira diferencia uma área interna a si mesma, o chamado "pensamento social e político brasileiro". Note-se a avaliação de Lúcia Lippi, relacionando o afastamento do pensamento brasileiro em relação à ciência política como decorrente dos pressupostos positivistas e utilitários dominantes nessa última área do saber:

Ela [a área do Pensamento Social e Político Brasileiro] se distancia da ciência política e da economia como praticadas hoje em dia já que tais disciplinas adotaram princípios mais formalistas, mais calcados em modelos que tomam o indivíduo como centro de decisões racionais. (Schwarcz, 2011: 145).

Esse último campo caracteriza-se por ser mais interdisciplinar, congregando, sobretudo, cientistas políticos, sociólogos, antropólogos e historiadores, do que de ciência política propriamente dita. ${ }^{10}$ Há que se evidenciar também a tremenda densidade teórica a que se chegou nessa subárea, com a publicação de inúmeros e significativos estudos realizados nas últimas décadas (Schwarcz, 2011).

Todavia, é notório que a grande maioria desses trabalhos centra a análise em um ou poucos autores, ou escolas de pensamento, particularmente oriundos do período da primeira metade do século XX; raros são os esforços de síntese em que grandes tendências da inteligência nacional sejam identificadas. Também não é comum encontrar estudos que investiguem a vinculação entre as obras dos pensadores brasileiros e as práticas políticas do país (a não ser para caracterizá-las, como foi comum num certo período do país, como ideológicas). ${ }^{11}$ Esses trabalhos acabam

\footnotetext{
${ }^{10}$ É sintomático que a $\mathrm{ABC}$ (Associação Brasileira de Ciência Política), entidade científica que reúne pós-graduados nessa ciência, fundada em 1996, tenha um grupo de trabalho permanente de teoria política, abarcando especialmente estudos de teoria normativa, e não tenha um espaço para a área de pensamento brasileiro (Almeida, 2005: 115). É a ANPOCS (Associação Nacional de Pós-Graduação e Pesquisa em Ciências Sociais), organização acadêmica brasileira que reúne pesquisadores de formação diversa, que mantém um espaço constante para a discussão dessa subárea.

${ }^{11}$ Claro que existem exceções. Uma excelente análise dessa relação, por exemplo, é estabelecida por Milton Lahuerta a respeito da sociologia paulista na segunda metade do século passado, com particular acento para obra de Fernando Henrique Cardoso (2001).
}

assumindo, mesmo que tacitamente, que são mais propriamente estudos de história das ideias do que de teoria política, produzindo com frequência uma verdadeira coletânea de memórias dos autores. Como resume Arruda em recente simpósio de balanço dessa subárea:

Penso que a área do pensamento social e interpretações do Brasil cresceu e tornou-se consideravelmente mais complexa nos últimos anos. É visível o volume de trabalhos publicados nessa área temática, como é também ponderável a diversidade de assuntos e das abordagens. A despeito disso, domina, em minha opinião, o tratamento dos intelectuais que marcaram a vida cultural brasileira, examinados seja no prisma de suas trajetórias individuais, seja na perspectiva da sua geração. Há também nítida concentração de estudos na geração de 1930, analisada em várias dimensões, revelando a preferência pelos chamados ensaístas modernistas. Do ponto de vista teórico-metodológico, creio que há grande diversidade, o que é, em princípio, muito bom. Porém, tendo em vista o caráter variado de estudos, confunde-se muitas vezes, diversidade com carência de rigor, visível na construção de puros retratos das personagens em escrutínio (Schwarcz, 2011: 141-142, grifos nossos).

Em resumo, são produzidos estudos de excelente qualidade nessa área, mas que se caracterizam por focar momentos isolados do pensamento brasileiro, sem produzir quadros ampliados de interpretação e com clara inclinação biográfica.

É preciso lembrar também que a consolidação acadêmica das Ciências Sociais brasileiras envolveu, ao tentar se equiparar com o padrão científico internacional, uma postura de rejeição, ou, ao menos, em que se desprestigiava a tradição nacional de estudos de política já existente como "ensaísta". Bernardo Sorj avalia que há uma tendência generalizada de "reinventar a roda" nos estudos de política no Brasil, quer dizer, de ignorar a produção intelectual do passado, supondo que "o país do futuro pouco tem a ganhar das gerações anteriores e que o Brasil é um país a ser periodicamente inventado" (2001: 104). Viveríamos numa situação de "desfiliados", haja vista que não há continuidade entre as gerações de intelectuais, nem cumulatividade de conhecimento (Sorj, 2001: 100-101). Como vimos, parecer semelhante é formulado por Gláucio Soares (2005), antes mencionado, de que há alienação e colonialismo teórico na ciência política brasileira, bastante atenta à produção teórica dos países do capitalismo central 
e ignorante quanto aos que se produz na periferia do mundo.

O tema da imitação intelectual tem uma longa história no Brasil, no qual se inserem os textos de Sorj e Soares acima citados. Embora não tenha sido o primeiro a denunciar uma suposta tendência mimética de seus pares (basta lembrar, entre outros casos, a crítica de Oliveira Vianna a Rui Barbosa no início do século XX), um intelectual tratou desse tema de modo paradigmático: Guerreiro Ramos.

Segundo esse pensador baiano, não existia rigorosamente, pelo menos até 1958 , um pensamento sociológico brasileiro. Isso porque, apesar de constituirmos uma nação formalmente livre no mundo desde 1822 , não teríamos ainda eliminado as formas de pensamento colonial. Viveríamos, portanto, em uma situação de alienação cultural, produzindo um pensamento não-funcional, do ponto de vista das necessidades reais do país, e servil e mecânico, em relação à incorporação da produção intelectual internacional. Contra uma "sociologia enlatada", Ramos propunha uma sociologia marcada pela "redução sociológica" que consistiria em, ao contrário da repetição acrítica de categorias e modelos exógenos importados por nossos intelectuais, ou de um simples revanchismo nacionalista, assimilá-los às condições da nação brasileira de modo a fundar uma sociologia autêntica como um processo coletivo - e não-circunscrito às elites intelectuais - e real, reduzido às condições de uma ex-colônia escravocrata, como o Brasil; a sociologia deveria constituir, ao contrário de sua prática nas academias brasileiras, como entende o autor, um "saber de salvação" (Ramos, 1996: 11), possibilitando à sociedade assenhorar-se de si mesma em prol de um projeto político autônomo. Parte desse projeto de fundação de uma nova sociologia implicava na recuperação dos antecedentes da redução sociológica nas tradições de pensamento brasileiro, algo realizado pelo próprio Guerreiro Ramos em relação a diversos autores, como Sylvio Romero, Euclides da Cunha, Alberto Torres, etc. $(1957,1996)$.

Esse tema - da autenticidade do pensamento político brasileiro - é retomado de modo distinto ao de Guerreiro Ramos, mas igualmente crítico, por Raymundo Faoro. Em texto já citado aqui anteriormente, Existe um pensamento político brasileiro?, o autor, avaliando a formação da inteligência nacional como um desdobramento da cultura política lusitana e europeia, chega à polêmica conclusão de que não há um pensamento político propriamente nacional. À luz das matrizes liberais europeias e estadunidenses, Faoro assevera que o liberalismo brasileiro, diferentemente dos modelos originais, se constitui como "farsa das elites" que, a despeito de todo discurso, mantém-se ciosas do status quo pré-moderno, escravagista e autoritário, não constituindo, destarte, uma prática política liberal, caracterizada pelo autor como um catálogo de direitos e garantias individuais contra os abusos do Estado e de agentes particulares.

Poder-se-ia inferir da tese de Faoro a predominância de um puro pragmatismo político; interpretamos, todavia, que longe de isso atestar a pouca relevância dos ideais e das linguagens políticas na vida brasileira, o que Faoro quer criticamente destacar é que essas tradições não completaram sua formação enquanto pensamento político, pensamento a orientar a práxis política, de modo que são outras linguagens e valores (não-liberais e não-democráticas) que imperam no país.

Novamente cumpre retificar: nem sempre os intelectuais brasileiros adotaram a atitude de rejeição ao pensamento brasileiro, como sugerem Ramos, Sorj e Soares. Pode-se encontrar em um ou outro autor (como é o caso do próprio Guerreiro Ramos) a intenção declarada de "dialogar" com nosso passado intelectual. Todavia, é fato que, com mais frequência até a primeira metade do século $\mathrm{XX}$, julgou-se que esse passado intelectual servia apenas como crônica de nossa história política, tendo mais valor como documento histórico do que como conhecimento científico. A negação, em maior ou menor grau, das tradições de pensamento brasileiro, está, assim, associada ao próprio processo de consolidação acadêmica de um "novo" saber, como explicam André Botelho e Milton Lahuerta:

O processo bem sucedido de institucionalização das Ciências Sociais no Brasil, iniciado com sua implantação como cursos universitários na década de 1930 (Miceli, 1995), mas cujos principais resultados, em termos de produção do conhecimento, começaram a surgir apenas em torno da década de 1950 não raro levou a minimização da relevância da tradição intelectual anterior genericamente identificada como "pensamento social e político". É claro que mesmo a geração pioneira da institucionalização soube reconhecer, ainda que de modo extremamente seletivo e desigual, o papel das gerações anteriores, sobretudo a dos ensaístas dos anos 1920-30, no processo de formação das ciências sociais no Brasil (Candido, 1950; Ramos, 1961; Fernandes, 1980). No entanto, como se tratava de demarcar um "campo científico", o próprio desenvolvimento das ciências sociais foi pensado, em termos gerais, a partir de uma polarização mais ou menos disjuntiva entre o "caráter científico das ciências sociais" e o 
"pré-científico" do pensamento social e político. (Botelho e Lahuerta, 2005: 7, grifos nossos).

Em avaliação feita no fim dos anos 1960, Wanderley Guilherme dos Santos destacava, igualmente, a pouca atenção dada à "história intelectual brasileira":

Com a única exceção dos artigos de Guerreiro Ramos, os demais textos abordam a matéria com forte "bias" institucional, em vista do que esta herança é imediatamente classificada como pré-científica, pela única razão de ter sido produzida antes da criação das escolas de Ciências Sociais. Costa Pinto, Djacir de Menezes, Fernando de Azevedo, Florestan Fernandes mostram a mesma atitude com respeito à produção cultural pré-institucionalizada no Brasil: considerando que a institucionalização da atividade científica teve início apenas na década de 30, tôda produção anterior a esta data constitui-se de ensaios mais ou menos irrelevantes; portanto, é desnecessário, senão, inútil, descobrir, organizar e discutir qualquer predecessor eventual dos tempos modernos (Santos, 1970: 147, grifos nossos, ênfase do autor).

Santos, nesse caso, contesta fortemente a visão institucionalista sobre o pensamento brasileiro, identificando na obra de Florestan Fernandes a expressão mais atualizada dela. Assim, como bem observam Keinert e Silva, Santos, ao defender a existência prévia de uma robusta reflexão sobre a política no Brasil anterior à institucionalização das ciências sociais, está contestando fortemente "o mito da fundação" difundido pela Escola de Sociologia paulista que constituiria o marco da verdadeira ciência política e sociológica no país (2009: 240).

Além da suposta menor "cientificidade", as formas de reflexão sobre o Brasil, datadas do período anterior à institucionalização das Ciências Sociais, foram, por algum tempo, caracterizadas como fortemente ideológicas. O ensaísmo brasileiro seria politicamente interessado, de forma que sua meta era menos "explicar" a realidade e mais "agir" sobre ela. O caso mais exemplar dessa avaliação foi o tratamento claramente negativo dado à produção intelectual do ISEB (Instituto Superior de Estudos Brasileiros), caracterizado genericamente como uma "fábrica de ideologias" (Toledo, 1977). Longe de ser uma exceção, o mesmo pode-se dizer, conforme a opinião de Botelho e Lahuerta, acerca da interpretação hegemônica na sociologia paulista sobre as tradições "nacionalista", "desenvolvimentista" e "populista". (Botelho e Lahuerta, 2005: 10).

Como bem resume Lessa, a criação da ciência política brasileira, com seu surgimento no final dos anos 1960 e com a determinação de seus padrões disciplinares em torno das décadas 1970-80, envolveu, assim, um duplo processo: por um lado, a incorporação dessa história de "curta duração" (não mais do que quatro gerações de cientistas políticos formados no país) numa perspectiva mais larga, em que a ciência política estadunidense, com sua forte inclinação behaviorista, foi determinante e, por outro lado, a ruptura e a demarcação crítica com representações de um passado existente sobre a política, o chamado "pensamento brasileiro" (2011: 20-21). Discordamos, destarte, de Keinert e Silva (2009) para quem a "inovação acadêmica" não exclui a reivindicação de pertencimento a uma tradição intelectual nacional; embora isso seja verdadeiro no pensamento de alguns desses politólogos, não expressa, todavia, a tendência geral e mais forte.

Lessa salienta o aspecto da "autonomização" do político e do campo disciplinar da ciência política brasileira. Se a tradição "ensaísta" sempre esteve atenta aos fenômenos políticos, pelo menos desde a fundação do Estado brasileiro, ela não reclamou uma autonomia da política como dimensão do real, como viria acontecer com os cientistas políticos a partir de fins da década de 60 (em busca da delimitação de sua ciência) que contestaram, em maior ou menor medida, os "historicismos", "sociologismos", "economicismos", etc. na análise política. Como já havíamos destacado a respeito da obra de Wanderley Guilherme dos Santos (Moreira, 2008), particularmente sobre Sessenta e quatro: anatomia da crise, como obra expressiva de um momento de fundação da linguagem da moderna ciência política brasileira, Lessa assevera:

Ao contrário de narrativas, típicas do universo mental anterior a 1964, nas quais a política era percebida como efeito de dinâmica sociais e históricas mais amplas, a nova cultura científica tenderá a pôr em relevo a autonomia dos fenômenos políticos e institucionais. Vale dizer a sua capacidade de constituírem-se em certo sentido em causas de si mesmos e a exigir aproximações analíticas de corte internalista. (Lessa, 2011: 43, grifos nossos).

A autonomização da ciência política esteve, então, associada a uma ênfase no potencial explicativo das instituições políticas, tomadas como variáveis independentes, entendendo que a política consistiria numa dimensão própria da realidade social, que não se subsumi a estrutura socioeconômica (mas, ao contrário, muitas vezes a explica), dimensão essa que se identifica, grosso modo, com a esfera do Estado. Como diz Fábio Wanderley Reis criticamente a esse respeito: 
[...] a política teria a ver com entidades e processos que ocorrem no âmbito do Estado (na esfera formal dos poderes Executivo, Legislativo e Judiciário), estendendo-se no máximo, como no caso dos partidos políticos, a entidades que se orientam pelo objetivo de obter o controle do Estado. (Reis, 2007: 453).

O ônus, no entanto, dessa autonomização da ciência política, concentrando a análise nas instituições, é exatamente a inclinação a se distanciar das outras linguagens de entendimento da política, sobretudo a filosofia, a história e mesmo a sociologia, de modo que a própria a cultura fica relegada a um segundo plano.

Certamente que a postura em desqualificar o passado intelectual brasileiro tem se tornado menos comum, como sugere a referida expansão dos estudos sobre pensamento brasileiro. Em primeiro lugar, porque agora, numa fase pós-positivista, os critérios de distinção do conhecimento científico já foram duramente questionados. Se a qualidade do que é empírico foi posta sob judice, a discriminação entre uma "ciência social", mais "explicativa", e o pensamento brasileiro, mais "interpretativo", é difícil de ser sustentada (Lessa, 2011: 2).

Além disso, a crítica ao positivismo, como já foi mencionado, questionou duramente a suposta neutralidade de valores da ciência. Como demonstraram, por exemplo, os recentes trabalhos na historiografia anglo-saxã (em especial Skinner, 1999, 2010; Pocock, 2003), os textos políticos constituem inevitavelmente atos políticos por meio dos quais seus autores procuraram afetar a realidade, na medida em que estabelecem um diagnóstico da política e de seus problemas e em que sugerem um prognóstico, com normas de ação para que eles sejam superados. Nesse sentido, os autores brasileiros do passado, antes caracterizados e menosprezados como "ideológicos", sob esse novo prisma, não podem diferenciados dos do presente.

Todavia, apesar da expansão desse campo de estudos, entendemos que alguns dos preconceitos próprios àqueles que rejeitaram de antemão as tradições de reflexão do Brasil (como "pré-científicas" e "ideológicas"), permanecem, ainda que atenuados, entre os cientistas políticos do país. Por essa razão, assume-se quase consensualmente que a produção do campo do pensamento brasileiro não interfere realmente sobre a literatura "empírica" de ciência política. De fato, como alertamos, os estudos "teóricos" raramente se dedicam a explicitar as relações entre as ideias estudadas e a prática política contemporânea, dando por vezes a impressão de que as modificações no plano cultural e intelectual ocorrem por fatores internos a esse campo. Além disso, é comum que dentro do próprio campo, a teoria política se diferencie do pensamento brasileiro a partir da suposição de que no último campo se faz mais (para usar a terminologia de Ball) "teorização de segunda ordem", uma vez que nos dedicamos a "estudar, ensinar e comentar os clássicos" do Brasil. Todavia, o fato dos estudos de pensamento brasileiro assumir com frequência o desenho de pesquisa de história de ideias "passadas" denota uma deficiência nesse campo já notada acima, mas não implica necessariamente que não se faça "teorizações de primeira ordem", isto é, que se teorize sobre as questões mais importantes da política, nem que essas ideias não permaneçam presentes na cultura política do país. Podemos dizer, mais uma vez recorrendo à distinção de Ball, que é possível ao mesmo tempo aprender sobre e com os pensadores brasileiros.

Em resumo, chegamos nesse ponto às seguintes conclusões. Os estudos de teoria política se afastaram, no século passado, da ciência política, que emergiu como campo de conhecimento independente das demais humanidades, principalmente da filosofia e da história. Um fator determinante nesse processo foi o domínio do modelo norte-americano de ciência política que, desde a revolução behaviorista, assumiu um contorno empiricista e com pouca atenção à dimensão teórica. Como resultado, por um lado, os estudos empíricos de ciência política ficaram prejudicados pelo uso restrito e instrumental da teoria (chegando ao corolário extremo de que os conceitos e valores políticos não interferem na prática política), ao passo que, por outro lado, os estudos de teoria política, encastelados nos próprios limites dessa subárea, assumiram ou um caráter puramente normativo ou de "história das ideias". No Brasil, como vimos, todo esse processo foi recebido de um modo um pouco distinto: os estudos de ciência política eram mais diversificados do que os nos Estados Unidos, o que redundou, em alguns casos, numa maior importância dada à teoria política, mas que frequentemente não permitiu que a dimensão teórica fugisse às alternativas antes citadas. Fator adicional nesse processo foi que, com bastante recorrência, os estudos de ciência política não incorporaram com centralidade as reflexões do passado intelectual brasileiro. Não obstante, se criou dentro do campo epistêmico mais amplo das ciências sociais, outra subárea que reconhecia a existência desse passado, o pensamento social e político brasileiro. Todavia, esse reconhecimento, por sua vez, não foi suficiente para que os trabalhos dessa subárea pudessem investigar com sistematicidade a vinculação entre as ideias políticas brasileiras e a prática política em nosso país. Por maior densidade que essa área de estudos venha alcançando nas últimas 
décadas, ainda são raros os trabalhos que não se limitam à interpretação de pensadores isolados ou de escolas de pensamento e que deem especial destaque à vinculação supracitada. Tudo se passa como se os pensamentos sobre a realidade política brasileira tivessem pouco a informar sobre ela na atualidade, de sorte que todo esforço nessa área se resumisse a registrar as ideias políticas como fatos "perdidos" no passado. A política, tal como vivenciada "na prática" seria puramente pragmática, uma luta pelo poder, não sendo afetada por essas ideias e ideais.

Obviamente que muito se conquistou com a crescente especialização entre aqueles que estudam a política, tanto na área "teórica" quanto nos estudos mais "empíricos": trabalhos mais rigorosos, do ponto de vista do método e da fundamentação "empírica", estudos de extrema erudição, especialmente entre aqueles que se dedicam a estudar a "teoria", etc. O avanço na análise da realidade política com o emprego de novas técnicas de pesquisa é considerável, como demonstram muitos dos denominados "estudos empíricos da política". ${ }^{12}$ Não é o caso de renegar ou subestimar as vantagens do processo de divisão social do trabalho intelectual, mas de encará-lo criticamente, alertando para a tendência ainda presente em que teoria e prática política ficam apartadas uma da outra, do ponto de vista da análise, quando se teria muito a ganhar em pensar ambas como parte de uma mesma realidade. Tomar como uma unidade o "mundo mental" e o "mundo material", as dimensões subjetivas e objetivas da política poderá fornecer à ciência política novas formas de compreensão dos fenômenos por ela investigados.

É necessário também lembrar que o processo de "declínio" da teoria política foi aparentemente revertido por volta dos anos de 1970, produzindo um crescente interesse nessa área. Pensando, sobretudo, no contexto estadunidense, Ball avalia que esse "renascimento" é decorrente de diversos fatores, entre eles, o declínio do positivismo lógico, duramente atacado então, e do qual se nutriu a abordagem behaviorista; as inúmeras reações aos diagnósticos sobre o "fim das ideologias" e que se basearam na recuperação das tradições políticas; a irrupção de inúmeros movimentos sociais de contestação que colocaram na pauta do dia questões centrais da teoria política; a obra clássica de Rawls já mencionada que, nesse contexto de crescente ativismo político, destacava, a despeito de todo seu formalismo, a questão precípua da justiça; por fim, também os

\footnotetext{
${ }^{12}$ Uma visão mais geral da ciência política brasileira é apresentada em diversos artigos que compõem os seguintes livros: Miceli, 1999; Martins, 2010
}

estudos formulados em torno à Escola de Cambridge, como os trabalhos de Peter Laslett, Quentin Skinner, John Pocock, entre outros, numa perspectiva mais fortemente historiográfica do que a de Rawls.

Mesmo constatando seu "retorno", Ball considera que a teoria política ainda deve restabelecer as relações com as investigações "empíricas", para benefício da própria ciência política. O mesmo parecer é formulado por Lessa, com o qual concordamos, para quem não é o caso de "recusar a 'vocação empírica' da ciência política, em nome de um tratamento pretensamente filosófico" (2005: 55), mas de procurar repensar o que é considerado como objeto precípuo de exame dessa ciência. Isso significa que devemos considerar pensamentos, conceitos, ideias, ideais, linguagens - elementos do que se convenciona entender como "objetos" da teoria política - como tão "empíricos" quanto instituições, partidos, políticas públicas - "objetos" que compõem a ciência política mainstream, superando a dicotomia entre "real", "prático", "empírico", de um lado, e "cultural", "ideal", "mental", de outro.

O desiderato deste trabalho é atuar no mesmo sentido do movimento de "retorno" à teoria política, não supondo se tratar de uma simples recuperação histórica de ideias passadas, nem tampouco transformar a teoria política em uma área de pesquisas puramente filosófica, mas de ter particular atenção para a existência de outras visões sobre a política que historicamente podem ter sido obscurecidas pela hegemonia de certas ideias (Skinner, 1988, 1999). Além disso, as pesquisas de teoria política e de pensamento brasileiro devem estar atentas à permanência dessas ideias na história e na cultura política do país e para o seu impacto sobre o comportamento político dos atores. Como uma presença, notada ou não, esses pensamentos, valores, conceitos participam do cotidiano político brasileiro de tal modo que, sem eles, esse mesmo cotidiano seria incompreensível. Longe, portanto, da abordagem não-culturalista discutida logo ao início deste estudo, entendemos que a cultura se funde à realidade política "material" precisamente através da linguagem e que é elemento indissociável da vida política. Desse ponto de vista, da indissociabilidade da dimensão objetiva e da dimensão subjetiva da política, a disputa entre linguagens políticas deixa de ser compreendida como mera querela de eruditos e passa a ser considerada, ao mesmo tempo, como índice e como parte componente das disputas entre os interesses, que, como dizia Maquiavel, dividem inevitavelmente o corpo político (Lefort, 1991). 


\section{Referências}

Almeida, Maria Hermínia Tavares de. 2005. Ciência Política no Brasil: avanços e desafios. In C. Martins (org.), Para onde vai a pós-graduação em ciências sociais no Brasil. Bauru: Edusc, p. 105-121.

Almmond, Gabriel. 1998. Political Science: the history of the discipline. In R. Goodin e H. D. Klingemann (orgs.), A new handbook of political science. Oxford: Oxford University Press, p. 51-96. http://dx.doi. org/10.1093/0198294719.003.0002

Andrews, Christina. 2005. As policy sciences como "ciência": método e reificação. Perspectivas, São Paulo, 13-27.

Araújo, Cícero e Reis, Bruno. 2005. A formação do pós-graduando em ciência política. In C. Martins, (org), Para onde vai a pós-graduação em ciências sociais no Brasil. Bauru: Edusc, p. 51-72.

Ball, Terence. 2004. Aonde vai a teoria política?. Revista de Sociologia e Política. Curitiba, 23: 9-22.

Botelho, André e Lahuerta, Milton. 2005. Interpretações do Brasil, pensamento social e cultura política: tópicos de uma necessária agenda de investigação. Perspectivas, São Paulo, 28: 7-15.

Brandão, Gildo. 2008. Linhagens do pensamento político brasileiro. São Paulo: Hucitec.

Faoro, Raymundo. 1994. Existe um pensamento político brasileiro?. São Paulo: Ática.

Faoro, Raymundo. 1993. A aventura liberal numa ordem patrimonialista. Revista USP, (17): 14-29.

Farr, James. 1999. Understanding conceptual change politically. In T. Ball (org), Political innovation and conceptual change. Cambridge: Cambridge University Press, p. 24-49.

Farr, James. 2006. The history of political thought as discipline genre. In J. Drysek; B. Honig; A. Philips (orgs), The Oxford of political theory. Oxford: Oxford University Press, p. 225-242.

Feres Junior, João. 2000. Aprendendo com os erros dos outros: o que a história da ciência política americana tem para nos contar. Revista Sociologia e Política, Curitiba, 15: 97-110.

Feres Junior, João. 2005. De Cambridge para o mundo, historicamente: revendo a contribuição metodológica de Quentin Skinner. Dados. Rio de Janeiro, 48(3): 655-680.

Feres Junior, João. 2009. Reflexão sobre o projeto Iberconceptos. In: J. Feres Junior (org.) Léxico da história dos conceitos do Brasil. Belo Horizonte: Ed. UFMG, p. 11-24.

Forjaz, Maria Cecília Spina. 1997. A emergência da ciência política acadêmica no Brasil: aspectos institucionais. Revista Brasileira de Ciências Sociais, 12(35): 101-120.

Goodin, Robert E. e Klingemann, Hans-Dieter (eds.). 1998. A New Handbook of Political Science. Oxford: Oxford University Press.
Gunnel, John. 1982. Interpretation and History of Political Theory: apology and epistemology. The American Political Science Review, 26(2): 317-327. http://dx.doi.org/10.2307/1961112

Jasmin, Marcelo. 2005. História dos conceitos e teoria política e social: referências preliminares. Revista Brasileira de Ciências Sociais. 20(57): 27-38.

Jasmin, Marcelo e Feres Junior, João. 2006. História dos conceitos: dois momentos de um encontro intelectual. In M. Jasmin e J. Feres Junior, História dos conceitos: debates e perspectivas. Rio de Janeiro: Ed. PUC-Rio.

Keinert, Fábio e Silva, Dimitri. 2009. La afirmación de a ciencia política em el Brasil: rupturas y continuidades. Prisma, (13): 239-252.

Kelley, Donald. 1990. What is happening to the history of ideas?. Journal of the History of Ideas, 51(1): 3-25. http://dx.doi.org/10.2307/2709744

Lahuerta, Milton. 1999. Intelectuais e transição: entre a política e a profissão. Tese (Doutorado em Ciência Política) - Faculdade de Filosofia e Ciências Humanas. Universidade de São Paulo.

Lahuerta, Milton. 2001. Intelectuais e resistência democrática: vida acadêmica, marxismo e política no Brasil. Cadernos AEL, 8(14): 57-92.

Lamounier, Bolívar. 1980. Pensamento político, institucionalização acadêmica e relação de dependência no Brasil. Dados, Rio de Janeiro, 23(1): 29-57.

Lamounier, Bolívar. 1982. A ciência política no Brasil: roteiro para um balanço crítico. In B. Lamounier (org.), A ciência política nos anos 80. Brasília: Ed. UNB, p.407-433.

Lefort, Claude. 1991. Pensando o político: ensaios sobre democracia, revolução e liberdade. Trad. Eliana Souza. Rio de Janeiro: Paz e Terra.

Lessa, Renato. 2010. O campo da Ciência Política no Brasil: uma aproximação construtivista. In: C. B. Martins (org.), Horizontes das Ciências Sociais no Brasil. São Paulo: ANPOCS, p. 13-49.

Lessa, Renato. 2011. Da interpretação à ciência: por uma história filosófica do conhecimento político no Brasil. Lua Nova, São Paulo, 82: 17-60.

Lima Junior, Olavo Brasil de. 1999. Partidos, eleições e Poder Legislativo. In S. Miceli (org), O que ler na ciência social brasileira? Vol. 3 - Ciência Política (1970-1995). São Paulo: Ed. Sumaré, p.13-57.

Limongi, Fernando. 1999. Institucionalização política. In S. Miceli (org), O que ler na ciência social brasileira? Vol. 3 - Ciência Política (1970-1995). São Paulo: Ed. Sumaré, p.101-155.

Losso, Tiago. 2011. A crítica de Charles Taylor ao naturalismo da ciência política. Revista Sociologia e Política, Curitiba, 19(39): 91-101.

Mainwaring, Scott e Liñan, Aníbal. 1998. Disciplina partidária: o caso da Constituinte. Lua Nova, 44: 107-136.

Mainwaring, Scott e Torcal, Mariano. 2005. Teoria e institucionalização dos sistemas partidários após a terceira onda de democratização. Opinião Pública, Campinas, XI(2): 249-286. 
Miceli, Sergio (org.). 1993. A Fundação Ford no Brasil. Sumaré: Fapesp.

Miceli, Sérgio. 1995. O cenário institucional das Ciências Sociais no Brasil. In S. Miceli (org), História das ciências sociais no Brasil. São Paulo: Vértice/ Sumaré, 2: 7-24.

Miceli, Sérgio. 1999. Intelectuais brasileiros. In S Miceli (org), O que ler na ciência social brasileira? Vol. 2 - Sociologia (1970-1995). São Paulo: Ed. Sumaré, p. 109-145.

Moreira, Marcelo Sevaybricker. 2008. O diálogo crítico com a teoria poliárquica no pensamento político de Wanderley Guilherme dos Santos. Dissertação de Mestrado em Ciência Política, Universidade Federal de Minas Gerais, Belo Horizonte.

Oliveira, Lúcia. 1995. As ciências sociais no Rio de Janeiro. In S. Miceli (org.), História das ciências sociais no Brasil. São Paulo: Vértice/ Sumaré, 2: 233-308.

Oliveira, Lúcia. 1999. Interpretações sobre o Brasil. In S. Miceli (org), O que ler na ciência social brasileira? Vol. 2 - Sociologia (1970-1995). São Paulo: Ed. Sumaré, p. 147-181.

Pécaut, Daniel. 1990. Intelectuais e a política no Brasil: entre o povo e a nação. São Paulo: Ática.

Pocock, John. 2003. Linguagens do ideário político. Trad. Fábio Fernandez. São Paulo: Ed. USP.

Przeworski, Adam; Alvarez, Michael; Cheibub, José e Limongi, Fernando. 1997. O que mantém as democracias?. Lua Nova, (40/41): 113-135.

Trad. Fábio Fernandez. São Paulo: Ed. USP.

Przeworski, Adam; Cheibub, José e Limongi, Fernando. 2003. Democracia e cultura: uma visão não-culturalista. Lua Nova, (58): 9-35.

Ramos, Guerreiro. 1957. Introdução crítica à sociologia brasileira. Rio de Janeiro: Ed. ANDES Ltda.

Ramos, Guerreiro. 1996. A redução sociológica. 3a ed. Rio de Janeiro: Ed. UFRJ.

Reis, Elisa. 1993. A construção intelectual e a política das ciências sociais brasileiras: a experiência do IUPERJ. In S. Miceli (org), A Fundação Ford no Brasil. São Paulo: Ed. Sumaré, p. 115-129.

Reis, Fábio. 1999. Institucionalização política (comentário crítico). In S. Miceli (org.), O que ler na ciência social brasileira? Vol. 3 - Ciência Política (1970-1995). São Paulo: Ed. Sumaré, p. 157-190.

Reis, Fábio. 2000. Brasil: "Estado e sociedade em perspectiva". In F. Reis, Mercado e utopia: teoria política e sociedade brasileira. São Paulo: Ed. USP, p. 229-256.

Reis, Fábio. 2004a. Dilemas da democracia no Brasil. In L. Avelar e A. Cintra (orgs), Sistema político brasileiro: uma introdução. Rio de Janeiro: Fundação Konrad-Adenauer-Stiftung.

Reis, Fábio. 2004b. Deliberação, interesses e "sociedade civil". In V. Coelho e M. Nobre (orgs), Participação e deliberação: teoria democrática e experiências institucionais no Brasil contemporâneo. São Paulo: Ed. 34 , p. 63-93.
Reis, Fábio; Reis, Elisa e Velho, Gilberto. 1997. As ciências sociais nos últimos 20 anos: três perspectivas. Revista Brasileira de Ciências Sociais, 12(35): 7-28.

Santos, Wanderley. 1970. Raízes da imaginação política brasileira, Dados. Rio de Janeiro: IUPERJ, (7): 137-161.

Schirru, Giancarlo. 2010. Filosofia da linguagem e filosofia da práxis. In G. Vacca e A. Aggio (orgs), Gramsci no seu tempo. São Paulo: Contraponto, p. 309-337.

Schwarcz, Lilia e Botelho, André. 2011. Simpósio: cinco questões sobre pensamento social brasileiro. Lua Nova. São Paulo, 82: 139-159.

Schwartzman, Simon. 1991. As ciências sociais nos anos 90. In H. Bomeny e P. Birman (orgs), Assim chamadas ciências sociais: formação do cientista social no Brasil. Rio de Janeiro: UERJ: RelumeDumará.

Silva, Ricardo. 2009. História intelectual e teoria política. Ensaios Bibliográficos. Revista de Sociologia e Política, Curitiba, 17(34): 301-318.

Skinner, Quentin. 1988. Meaning and understanding in the history of ideas. In J. Tully, (ed), Meaning \& Context: Quentin Skinner and his critics. Princeton: Princeton University Press, p. 29-67.

Skinner, Quentin. 1999. Language and political change. In T. Ball, Political innovation and conceptual change. Cambridge: Cambridge University Press, p. 6-23.

Skinner, Quentin. 2010. Hobbes e a liberdade republicana. Trad. Modesto Florenzano. São Paulo: Ed. da Unesp.

Soares, Gláucio. 2005. O calcanhar metodológico da Ciência Política no Brasil. In C. Martins (org), Para onde vai a pós-graduação em ciências sociais no Brasil. Bauru: Edusc, p. 73-104.

Sorj, Bernardo. 1995. Estratégias, crises e desafios das Ciências Sociais no Brasil. In S. Miceli (org.), História das ciências sociais no Brasil. São Paulo: Vértice/Sumaré, 2: 311-339.

Sorj, Bernardo. 2001. A construção intelectual do Brasil contemporâneo: da resistência à ditadura ao governo FHC. Rio de Janeiro: J. Zahar.

Toledo, Caio. 1977. ISEB: fábrica de ideologias. São Paulo: Ática.

Veiga, Laura. 1992. A interação entre contexto, atividades e características organizacionais no mundo acadêmico. Análise e Conjuntura, Belo Horizonte, 7(2-3): 53-75.

Vianna, Luiz. 1997. A institucionalização das ciências sociais e a reforma social: do pensamento social à agenda americana de pesquisa. In Luiz Vianna, $A$ revolução passiva: iberismo e americanismo. $2 \mathrm{a}$ ed. Rio de Janeiro: Revan, p. 195-242. 